\title{
Breeding range of the last eastern colony of Critically Endangered Northern Bald Ibis Geronticus eremita in the Syrian steppe: a threatened area
}

\author{
GIANLUCA SERRA, CLAUDIA BRUSCHINI, JEREMY A. LINDSELL, \\ LUBOMIR PESKE and AHMED KANANI
}

\section{Summary}

Eight years after the discovery of the last survivors of the eastern population of Northern Bald Ibis in Syria, their breeding grounds within the Palmyra steppe remain threatened by habitat degradation, human disturbance and uncontrolled infrastructural development whilst the ibis colony size has continued to decline. This study is aimed at assisting national and international stakeholders in strengthening the Ibis Protected Area, established in 2004 and still lacking a clear boundary and management zonation, by quantitatively establishing the range used by these birds through use of satellite tracking and field observations collected between 2006 and 2009. The core breeding range used by the ibises is $224-253 \mathrm{~km}^{2}$ while the full home range is c.1,500 $\mathrm{km}^{2}$, encompassing a mountainous area north of Palmyra, ranging from 400 to $1,000 \mathrm{~m}$ asl. Locations from satellite tracking also revealed an important unknown post-breeding site. The ibis breeding area is also home to a range of other rare and endangered fauna as well as significant landscape, cultural and recreational assets, establishing it as an area of international importance. The Syrian steppe is a crucial socio-economic asset for the country, not only for the indigenous pastoralist people, but also because Syria seeks to develop and promote ecotourism in the Palmyra region. The steppe is increasingly suffering from damaging desertification. The need for investment in protection and management of key biodiversity and landscape assets is a precondition that needs greater recognition by the authorities. Recommendations are provided for decision makers and conservationists aimed at mitigating threats and making the Ibis Protected Area fully functional.

\section{Introduction}

The attention of international conservation organizations was directed to the Palmyran steppe when, in April 2002, a relict breeding colony of the 'Critically Endangered' Northern Bald Ibis Geronticus eremita (BirdLife International 2004) - declared as extinct from all Eurasia 13 years previously (Safriel 1980, Akçakaya 1990) - was rediscovered there (Serra et al. 2004). The Northern Bald Ibis thereby qualified as the most threatened bird in the Middle East (Serra 2003). Since the time of discovery the breeding colony has been protected, with variable efforts and success, by the Syrian authorities assisted by international organizations (Serra et al. 2009a,b). An Ibis Protected Area (IPA) was gazetted in 2004, covering the core area where the ibis bred, within the mountains north of Palmyra (Serra 2002, Serra et al. 2009c). The area was, several years later, declared as an Important Bird Area (SYo25, BirdLife International 2009).

This eastern population of Northern Bald Ibis undertakes an annual long-distance migration (Lindsell et al. 2009): adults arrive in the breeding grounds during the second half of February 
and leave around mid-July (Serra et al. 2009a). Despite protection efforts, the colony has been steadily decreasing in size, recently reaching alarming levels, due to low recruitment caused by very high mortality of immature ibises outside breeding range and recently also due to a sharp drop in breeding performance (unpubl. data).

Conservation of migratory endangered species and populations is certainly more challenging than dealing with resident ones: for instance, proper management and protection of breeding habitats was sufficient to ensure the survival of the western resident population of Northern Bald Ibis in Morocco (Bowden et al. 2003), and of the Critically Endangered, and resident, Crested Ibis Nipponia nippon in China (Xiao-Ping et al. 2009). However, protection and management of breeding grounds is an important starting point for migrants too, combined with protection of habitats along migratory routes and wintering sites (McNulty 1966, Schulz 1988).

The biodiversity and landscape heritage of the Palmyra steppe, where the IPA is located, are highly threatened by severe ecological degradation that started decades ago (Serra et al. 20ogb). An increasing population of indigenous mobile Bedouin pastoralists uses severely degraded pastures, the natural feeding habitat for ibises, as an open access resource (Serra et al. 2009b). The time of the year with the highest density of nomads coincides with the ibis breeding season (Serra et al. 2009a).

The traditional nomadic life style and the biodiversity heritage are both threatened by this ecological degradation whose proximate causes are over-grazing, collection of firewood and recreational hunting of wildlife. Consequently, the Bedouin pastoralists whose traditional livelihoods have been based on the use of natural resources for centuries (Savioli 2009) have experienced increased impoverishment during the last 10 years (De Schutter 2010). Moreover, the pressure of oil companies prospecting in the IPA is growing annually; they were granted prospecting concessions to drill wells within ibis core breeding area as early as 2003-2004 (unpubl. data).

The main issue is that the IPA, even six years after gazetting, essentially remains a "paper park". It still lacks a defined and agreed boundary, the allocation of permanent and qualified staff, a site management plan, and a programme for engaging the local community (Serra et al. 2009b).

In this study we make a contribution to the development of IPA as an operational protected area, the first of this kind in the country, by identifying and mapping the breeding range of the Northern Bald Ibis (IBR) and by providing conservation recommendations.

\section{Study Area}

The IBR is located c.20 km north of Palmyra $\left(34.60^{\circ} \mathrm{N}, 38.25^{\circ} \mathrm{E}\right)$ at the foothills of the Abu Rigimin mountain range and is centred on the mountain chain locally known as Jebel Abiad (Figure 1). The area is situated between 300 and $1,330 \mathrm{~m}$ asl (Figure 2). At the northernmost corner of Jebel Abiad is Jebel Matna, at 1,330 m, the highest summit within the IBR.

\section{Material and Methods}

Following discovery of the ibis colony, an intensive community-based protection programme was established and run for three subsequent breeding seasons (2002-2004) under an FAO/DGCS (Italian Cooperation Programme) project, during which local rangers from the Ministry of Agriculture were trained to protect, monitor and collect data on the ecology and behaviour of the birds at their breeding grounds (Serra et al. 2009c). From 2005 to 2009, the protection programme and research activities were carried out with the assistance of BirdLife International.

The IBR was assessed from a combination of locations obtained using satellite telemetry and field observations. Three adult ibises were tagged with satellite PTTs in June 2006 in the IBR (Lindsell et al. 2009) and two fully-grown birds were tagged in 2009 at the same location (unpubl. data). All three adult ibises were breeders while only one of the two full-grown birds was a breeder. Tags were active for $1.5^{-3}$ years, transmitting every $1.5^{-2}$ days. 


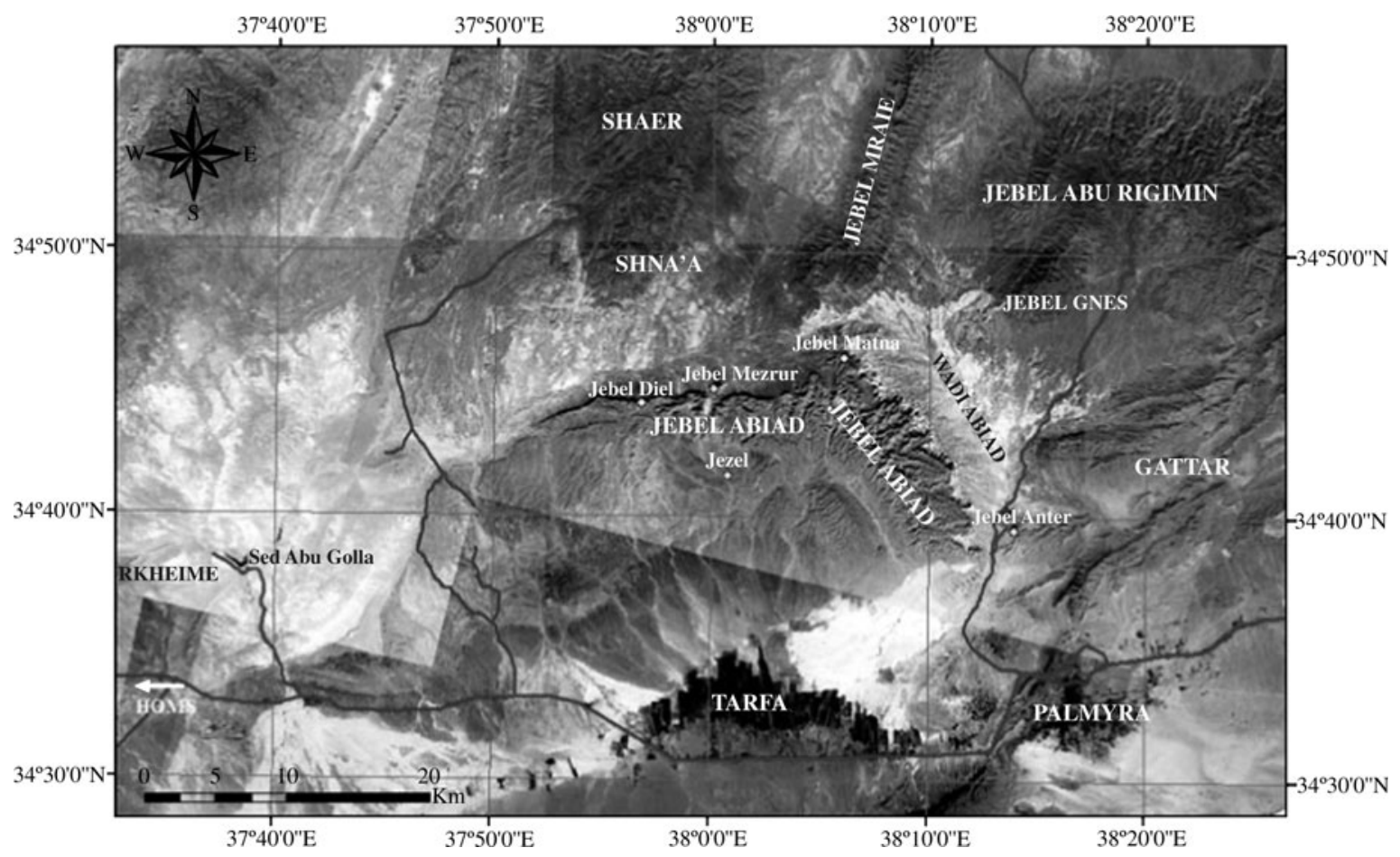

(1)

$\stackrel{5}{3}$

Figure 1. Satellite image of study area with indication of main topographic features. Satellite image courtesy of Petro Canada, map by C. Bruschini. 


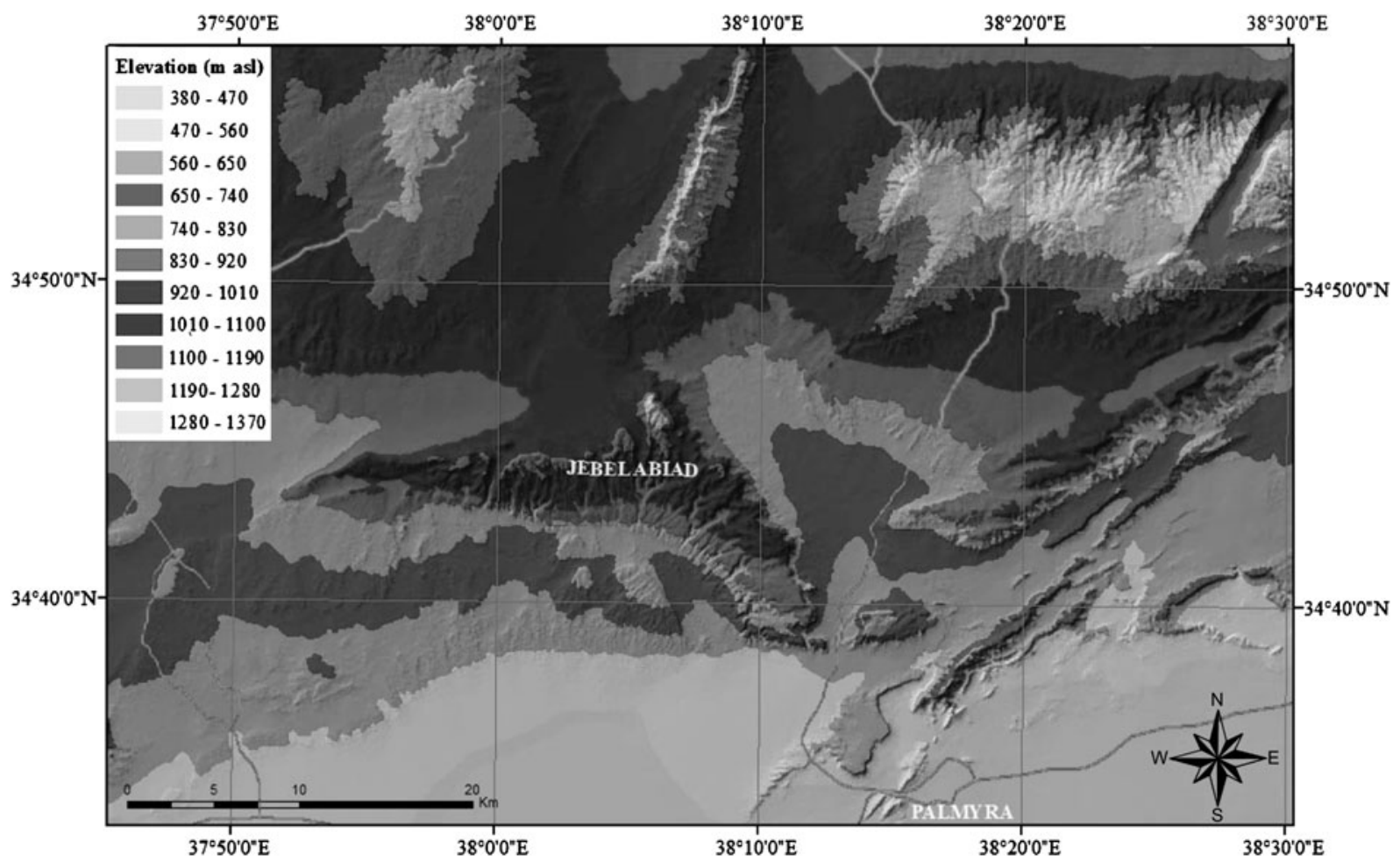

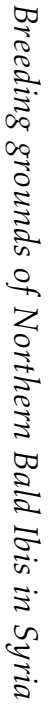

Figure 2. Elevation distribution of study area (m asl). Map by A. Savioli and C. Bruschini 
Satellite locations were received through the Argos Location Service Plus system from 2006 (Jun-Jul), 2007 (Feb-Jul), 2008 (Feb-Jul) and 2009 (Jul). Data in DIAG format were filtered by LC error classes (Argos User's Manual: http://www.argos-system.org/) and only locations with a stated accuracy ( $\mathrm{LC}_{3}-1$ ) and LCo were used for the analysis. Locations of the same bird less than 3 hours apart and less than $2 \mathrm{~km}$ apart were regarded as auto-correlated and the less precise one was discarded. Only $66.6 \%$ of $\mathrm{LC}_{3-1}$ locations fell within their predicted error interval, so locations were further filtered, taking into account the ellipse of estimated error associated with each LC type, on the basis of the following two standardised criteria:

1. Isolated locations. Very isolated locations that are not expected based on known ibis colony range and distribution of all other locations, or/and not expected based on habitat preferences, known roosts and ibis behaviour, were discarded.

2. False cluster of nocturnal locations. Clusters of nocturnal locations with no correspondence with any actual known or potential roost, and/or made by locations related to each other with an illogical temporal sequence, were discarded.

Visual observations were recorded during 2006 (June) and 2009 (March-July): road-transects, relatively uniformly distributed within study area and covering most ibis feeding habitats, were systematically covered once a week in search of the feeding birds. Predictable behaviour by the birds, high levels of ranger experience and good cooperation from pastoralists, ensured searches usually lasted less than one day.

Accuracy of visual observations was regarded as equivalent to that of $\mathrm{LC}_{3}$ satellite locations (error $<250 \mathrm{~m}$ ), based on the average observation distance of ibises by rangers and on the typical GPS position error.

Locations were combined and analysed using ArcGIS software with Hawth's Analysis Tools for ArcGIS (www.spatialecology.com/htools/index.php). We used the fixed-kernel range estimator (Worton 1989) to estimate the $50 \%$ and $95 \%$ utilisation distribution with least squares crossvalidation for smoothing (Seaman and Powell 1996, Hooge et al. 2004). We calculated the area of each kernel and the associated Minimum Convex Polygon (MCP).

\section{Results}

A total of 443 satellite and 50 visual locations were compiled. Of these, 159 satellite locations $(36 \%)$ were discarded due to uncertain error (i.e. LCA, B and Z), 115 locations (26\%) were discarded due to auto-correlation and 64 locations ( $14 \%$ ) were discarded in accordance with the two criteria listed in the methods. This resulted in a dataset of 155 locations $(54=\mathrm{LCo}, 39=$ $\mathrm{LC}_{1,9}=\mathrm{LC}_{2}, 3=\mathrm{LC}_{3}$, and 50 visual observations), for four satellite-tagged adult Northern Bald Ibises during June 2006-July 2009 (Figure 3). Kernel at 95\% and 50\% levels can be regarded as the overall ibis colony breeding range (light-coloured) and the core breeding range (dark-coloured), respectively. The surface of the Minimum Convex Polygon (MCP) enclosing all 155 locations was $1,514.1 \mathrm{~km}^{2}$, while the area of kernel distributions was $1,313.5 \mathrm{~km}^{2}$ (at $95 \%$ ) and $253.0 \mathrm{~km}^{2}$ (at 50\%). When LCo satellite locations were excluded ( $n=101$ ), the overall pattern of the kernels was very similar and their ratio (50\%:95\% kernel) was comparable: 0.21 (using $\mathrm{LC}_{1-3}$ ) versus 0.19 (using LCo-3). The area was slightly reduced using LC1-3 data: the MCP was 1 ,066.o $\mathrm{km}^{2}$, whilst the area of the kernel was $1,071.7 \mathrm{~km}^{2}$ (at $95 \%$ ) and $224.4 \mathrm{~km}^{2}$ (at $50 \%$ ).

Examination of Figures $1-3$ shows that the IBR comprises Rkheime to the west, and Gattar to the east, the croplands of Tarfa to the south, and Shna'a and Jebel Abu Rigimin to the north. The altitudinal range most used by the birds was $300-900 \mathrm{~m}$ : the birds were never seen to use the highest elevations of the Jebel Abu Rigimin mountain range, clearly preferring the foothills (Wadi Abiad and Gattar) and the mid-altitude plateau of Mazrur Dreile-Shana'a.

The area at Rkheime was used by birds after the end of the breeding season, in some years. When breeding performance was good, they used the area for 1-2 weeks after they left the core 


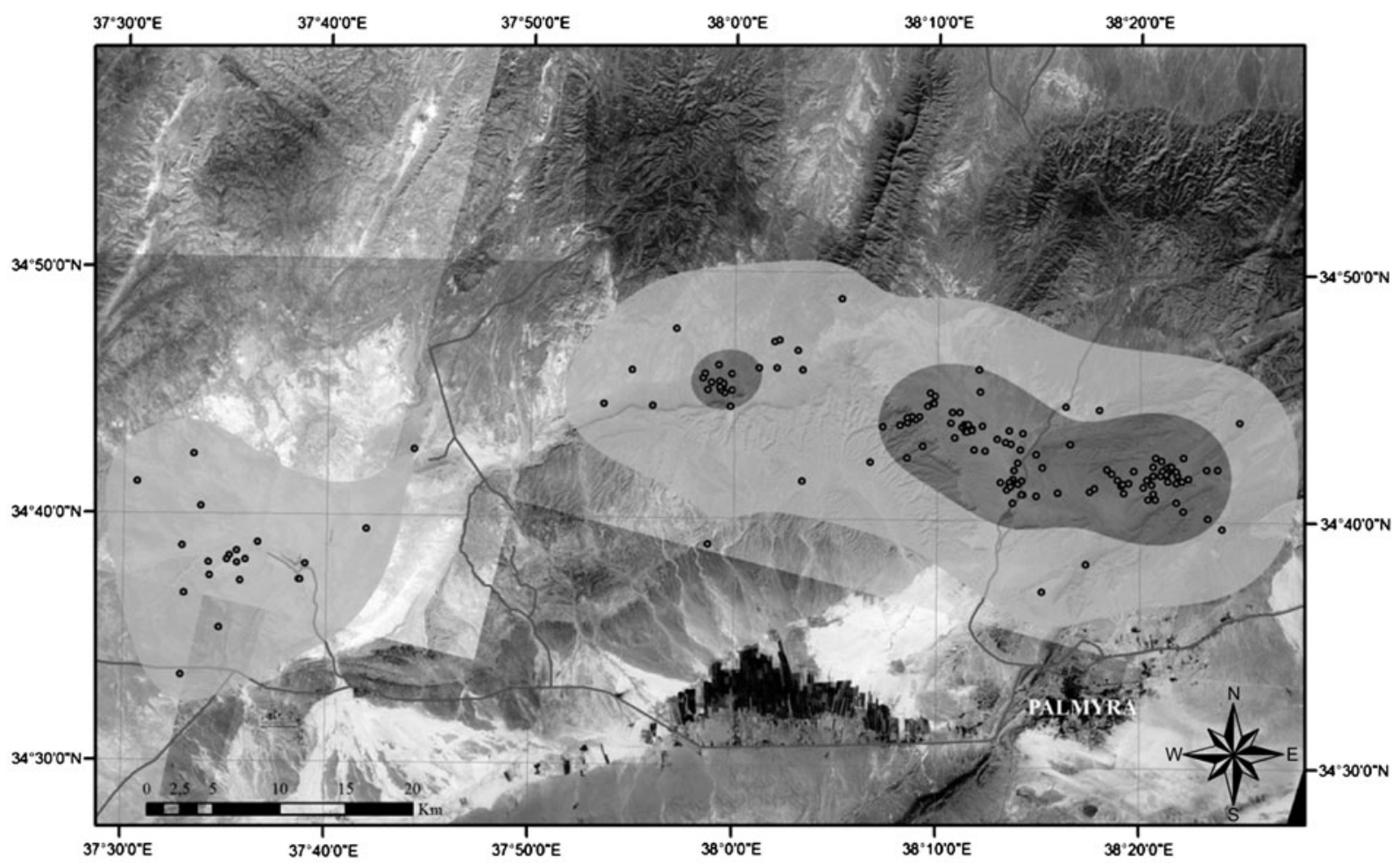

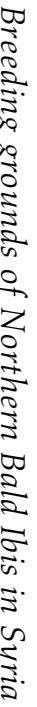

Figure 3. Kernel distributions (light-coloured $=95 \%$; dark-coloured $=50 \%$ ) of satellite locations (LCo-3, $n=105)$ and visual locations $(n=50)$. Area of $95 \%$ kernel $=1,313.5 \mathrm{~km}^{2}$; area of $50 \%$ kernel $=253.0 \mathrm{~km}^{2}$. Satellite image in the background courtesy of Petro Canada, map by C. Bruschini. 
breeding area in July. Following breeding failures in June 2008 and 2009, ibises were observed to use this area for over a month.

\section{Discussion}

\section{Ibis breeding range}

The locations derived from satellite tracking provided a more reliable map of the breeding range of the Northern Bald Ibis in Syria than using field data alone. Satellite telemetry in combination with kernel fitting has been widely used for estimating the spatial use of habitats (e.g. Hobbs et al. 2005, Vashon et al. 2008). However, the proportion of low-accuracy satellite locations in the Syrian steppe was exceptionally high compared to other areas and countries, probably due to interference from other bandwidth users. No less than $50 \%$ of satellite locations had to be discarded due to large or uncertain errors, and of the remaining locations, only $49 \%$ had defined errors (LCI-3). This constraint required us to integrate the satellite and field data.

The foothills in the IBR once supported large colonies of Northern Bald Ibis breeding on the sheer cliffs, a common sight in the Syrian steppe until only 20-30 years ago (Serra et al. 2004). By 2010, only one breeding pair remained, the sole site in the Middle East (Serra pers. obs.).

The core IBR, already known from long-term field observations and monitoring (Serra et al. 2008, 2009a), was confirmed by the 50\% kernel, while knowledge of the wider breeding range was improved with the $95 \%$ kernel. The core breeding area did not change significantly when LCo locations were excluded.

The wider breeding range used by the last two Northern Bald Ibis pairs in Syria, during four consecutive breeding seasons (2006-2009), is about 4-5 times larger than that used by dozens of pairs, from few adjacent colonies, belonging to the western population of the same species breeding in Morocco (C. Bowden pers. comm.). This difference might be due to the wetter conditions in the Moroccan coastal steppe (Bowden et al. 2003) and to the documented ecological degradation of the Syrian steppe (Serra et al. 2009b), and perhaps even to a lack of social facilitation at the Syrian colony in efficiently detecting suitable feeding areas (Ward and Zahavi 1973). On the other hand, despite the differences in the environment, the wider breeding range of Northern Bald Ibis in Syria is very similar in size to that estimated for the Black Stork Ciconia nigra during the nestling period in Europe (Jiguet and Villarubias 2004). The difference in the ratio core:wider breeding range between the two species (0.19-0.21 in the ibis versus $0.43^{-0.80}$ in the stork) might be related to the more disperse feeding habitats used by the Black Stork during the breeding season (Jiguet and Villarubias 2004).

The breeding habitat used by the ibises is a rugged rocky steppe characterized by plateaux and sheer cliffs, intersected by a few large wadis (dry drainages) and many small lateral wadis, and supporting very sparse scrubby vegetation (Serra et al. 2008).

Importantly, the analysis in the present study has underlined the existence of a very important and little-known post-breeding staging area (Rkheime), used by the ibises for a variable period according to year (not all years) and to breeding performance, soon after the core breeding area is vacated.

\section{Relevance of IBR}

The occurrence of this handful of Northern Bald Ibises makes the area unique regionally and internationally, together with what is possibly the last wild herd of Arabian Sand Gazelles Gazella subgutturosa marica in Syria and one of the last two colonies of Griffon Vulture Gyps fulvus, in addition, Lesser Kestrel Falco naumanni, regionally rare Wolf Canis lupus and Striped Hyaena Hyaena hyaena occur (Serra et al. 2009b). The supplementation of the wild gazelle population with those from a captive breeding centre located in the nearby Al Talila Reserve is a rare opportunity to create a viable wild population of gazelles in the country. 
Moreover, the relatively recent extinction from the IBR of the Nubian Ibex Capra nubiana and the Leopard Panthera pardus, and loss of important Pistacia atlantica woodland, raises prospects for the reintroduction of charismatic fauna and ecological rehabilitation through reforestation. Birdwatching potential in Palmyra steppe is high (Murdoch 2010) and specialised foreign operators have already started tours in Syria in the last few years.

Besides biodiversity, the site enjoys key ecological services of benefit to the local community, outstanding landscape and scenic views, strong cultural interest in traditional livelihoods on the steppe and significant recreational and tourism potential (Serra et al. 2009b). Indeed, the Syrian Government has recently set a strategic development goal for the Palmyra region (MAM 2008) promoting tourism on a greater scale by combining the outstanding archaeological and historical assets of Palmyra with its unique landscape and natural heritage included within Al Talila Reserve (Serra et al. 2009c) and the Ibis Protected Area (Serra et al. 2009b).

About to years after the first pioneering steps in conservation were taken in Palmyra (Serra et al. 2009c), nature conservation is now recognised by central Government as an opportunity for sustainable socio-economic development of the Palmyra region.

\section{Threats to the IBR}

Despite the international importance and the socio-economic opportunities associated with developing the protected area in a sustainable manner, threats to the assets of the area are on the rise in the short term. On a national scale, the economy, after recently opening to global markets, is growing rapidly and resources are sought with urgency and with little attention to environmental impact (e.g. Pitts-Tucker 2010). Pressure from a growing number of livestock has long since passed the carrying capacity of the fragile steppe ecosystem (Mirreh et al. 1998, 2000). Independent indications suggest that the ibis feeding habitats within IBR - the same pastures used by nomads - are ecologically degraded. Ibis foraging distances during the nesting period are longer than the averages recorded at other breeding sites (Serra et al. 2008); the size of the wider and the core IBR is 60 and 20 times larger, respectively, than those identified for the ibis wintering grounds in Ethiopia, estimated using the same method (Serra et al. in prep.); potential ibis prey is distributed patchily across the IBR (Lindsell et al. in press.); and artificial reservoirs, with their seasonal supplies of frogs, have become crucial for the survival and successful breeding of the ibis colony (Serra et al. 2008).

If no action is taken to reverse the ecological degradation of the steppe, there is a high risk that this environment could convert to a biologically low value desert (De Schutter 2010) and ecotourism potential would quickly diminish (Serra 2007, Serra 2008).

The IPA stands as a test case in Syria. Despite its documentation as the last haven for a nationally and internationally renowned bird species, the most threatened in the Middle East and one of the rarest in the world, six years after declaration of the protected area many crucial management requirements of the site remain unresolved - as is the case with other 23 protected areas established in the country in recent years (Anas Al Khen pers. comm., Serra pers. obs.). Critical issues are arising where corporations, with differing priorities, risk deflecting agreed government priorities with short term but major funding and there is often a recurring need to highlight those priorities to all concerned. In recent years a lack of well-defined boundaries and zonation for the IPA has led to conflict of interests with oil prospecting companies and poorly sited "ecotourism" infrastructure.

The IPA still holds the potential to become a model site and protected area in the country, where trials for controlling and halting desertification could be carried out and where benefits from conservation and responsible ecotourism go directly to the local community. But if Syria intends to harness this potential, there is an urgent need to realise that in order to promote ecotourism, investment and funds must be planned and allocated in the protection and management of key species and sites. In order to move towards this goal we make the following recommendations: 


\section{Recommendations}

Short-term (1-2 years)

Upgrade the Ibis Protected Area into a functioning protected area according to international standards

The core breeding range identified by the present study should be declared a strict conservation zone and the wider breeding range afforded buffer zone status. The strict conservation zone should also include the area occupied by sand gazelles and the post-breeding area used by the ibises at Rkheime. A zonation plan should be discussed and agreed by all stakeholders, including the local community (Serra et al. 2009b).

\section{Institutionalise a standard ibis protection programme}

Breeding performance of the ibis colony in Syria is strictly dependent on intensive protection from human disturbance, natural depredation and poaching (Serra et al. 2009a). It is therefore crucial to institutionalise and allocate proper funds for a standard and intensive seasonal protection programme, based on past experience and lessons learned, scientifically coordinated, and run every year (Serra et al. 2009b).

Carry out a thorough and independent environmental and social impact assessment for any development within the IPA

A multi-stakeholder committee should be established with the specific responsibility to evaluate all new plans for infrastructure development within the IPA. The committee will operate in line with Syrian Environmental Law n. 50, issued in 2002, envisaging preparation of environmental and social impact assessment studies prior to acceptance of development plans. Allowing advisory input by national and international conservation NGOs would render the process more efficient and objective.

\section{Manage the artificial reservoirs and protect associated vegetation}

Given the extreme ecological degradation of the area, even the occurrence of artificial water and vegetation (such as Tamarix tetragyna) can contribute to helping the whole ecosystem to survive. For instance, occurrence of frogs at the reservoirs was shown to be an important food source for ibises, especially during the critical nestling period (Serra et al. 2008). These reservoirs also provide excellent stop-over sites for migrating water birds and songbirds and are important livestock watering sites for Bedouin pastoralists. The reservoirs in the area are old and require maintenance to ensure they retain water; these sites also require protection from hunters.

\section{Medium-term (2-3 years)}

\section{Upgrade the IPA to the status of National Park in Syria}

The IPA qualifies well under the IUCN's Protected Area Management Categories (IUCN 2009), as a National Park (IUCN Category II). This would be the first in the country.

Rehabilitate the IPA pastures and scrublands through active involvement of indigenous pastoralists

This measure is crucial in order to revive the ecosystem and rehabilitate the pastures, increasing their resilience to drought. This may require some reform of national land tenure regulation for Syrian steppe, at least in the protected area. 
Engage local communities through sustainable development, including small-scale and controlled ecotourism (sensu Serra 2007, Serra 2008)

A 5-year IPA management and development framework has already been proposed (Serra et al. 2009b).

Assist competent authorities to prepare a national legal framework regulating the management of protected areas

This includes a scientifically-based zonation and management plan, qualified staff, integration of socio-economic needs of local communities and the promotion of responsible and controlled ecotourism. The lack of a national legal framework regulating protected areas and ecotourism is an historical constraint on conservation in Syria, as evidenced by threats to key sites elsewhere in the country (Serra et al. 2006, Anas Al Khen pers. comm.).

\section{Acknowledgements}

Special thanks go to the Desert Commission's General Manager Eng. A. Hamoud and the deputy director Eng. M. Nahaz. We thank the Italian Cooperation Programme (DGCS), National Geographic Society, RSPB, Finnish and Netherlands embassies in Damascus for funding. Management, institutional facilitation and support by the IUCN Regional Office for West Asia and BirdLife Middle East were crucial. Special thanks go to Mr Khaldoun Alomari, Protected Area Officer at IUCN ROWA. Petro-Canada kindly donated the satellite image of the study area and the right to use it.

\section{References}

Akçakaya, H. R. (1990) Bald Ibis Geronticus eremita population in Turkey: an evaluation of the captive breeding project for reintroduction. Biol. Conserv. 51: 225-237.

BirdLife International (2004) Geronticus eremita. In: IUCN 2006. 2006 IUCN Red List of threatened species. www.iucnredlist.org, downloaded on o9 June 2007.

BirdLife International (2009) Important Bird Areas on-line inventory. http://www.birdlife.org/datazone/sites/index.html?action $=$ SitHTMDetails.asp\&sid $=20772 \& \mathrm{~m}=0$, downloaded on 23 October 2009.

Bowden, C. G. R., Aghnaj, A., Smith, K. W. and Ribi, M. (2003) The status and recent breeding performance of the critically endangered Northern Bald Ibis Geronticus eremita population on the Atlantic coast of Morocco. Ibis 145: 419-431.

De Schutter, O. (2010) UN Special Rapporteur on the right to food: Mission to Syria from 29 August to 7 September 2010. Unpublished report to Office of the United
Nations High Commissioner for Human Rights.

Hobbs, R. C., Laidre, K. L., Vos, D. J., Mahoney, B. A. and Eagleton, M. (2005) Movements and area use of Belugas, Delphinapterus leucas, in a subarctic Alaskan estuary. Arctic 58: 1479-1487.

Hooge, P. N., Eichenlaub, W. M. and Solomon, E. K. (2004) Using GIS to analyze animal movements in the marine environment. Unpublished report. U.S. Geological Survey, Alaska: Biological Science Center. Available at: http://www.absc.usgs.gov/ glba/gistools, downloaded on 26 April 2010.

IUCN (2009) Protected areas and World Heritage Programme. http://www.unepwcmc.org/protected_areas/categories/index. html, downloaded on 23 October 2009.

Jiguet, F. and Villarubias, S. (2004) Satellite tracking of breeding Black Stork Ciconia nigra: new incomes for spatial conservation issues. Biol. Conserv. 120: 153-160. 
Lindsell, J., Serra, G., Abdallah, M. S., al Qaim, G. and Peske, L. (2009) Satellite tracking reveals the migration route and wintering area of the Middle Eastern population of Northern Bald Ibis. Oryx 196: 329-335.

Lindsell, J. A., Shehab, A. and Anderson, G. Q. A. (in press) Patchiness in prey levels increases vulnerability of Critically Endangered Northern Bald Ibises Geronticus eremita on their Syrian breeding grounds. Bird Conserv. Int.

MAM (2008) Palmyra Region Strategic Action Plan: A Strategy for Sustainable Development. Unpublished report to Ministry of Environment and Local Affairs and Municipal Administration Modernization (MAM), Project MED/2004/6264 - Europe Aid 119822/SV/SY.

McNulty, F. (1966) The Whooping Crane. New York, USA: E. P. Dutton.

Mirreh, M. M., Al Jundi, A. and Khaddour, H. (1998) Grazing management of Al Talila Reserve for bedouin camels. Unpublished report to FAO/DGCS (Italian Development Cooperation Programme), Project GCP/ SYR/oog/ITA.

Mirreh, M. M., Arru, G. and Batello, C. (2000) Towards formulation of drought management policies and strategies. Unpublished report to FAO/DGCS (Italian Development Cooperation Program), Project GCP/SYR/oog/ITA.

Murdoch, D. (2010) Bird sites of the OSME Region 6-Birding the Palmyra area, Syria. Sandgrouse 32: 61-79.

Pitts-Tucker, T. (2010) Cement factory sparks protest. Syria Today 63. Available at: http:// www.syria-today.com/index.php/may-2010/ 557-society/7727-cement-factory-sparksprotest, downloaded on 23 August 2010.

Safriel, U. N. (1980) Notes on the extinct population of the northern bald ibis Geronticus eremita in the Syrian desert. Ibis 122: 82-88.

Savioli, A. (2009) Ethnographic survey in the $\mathrm{N}$. Bald Ibis breeding grounds in November - December 2009. Unpublished report to IUCN/DGCS (Italian Development Cooperation Programme).

Schulz, H. (1988) Weißstorchzug. Weikersheim: WWF-Umweltforschung, 3 .
Seaman, D. E. and Powell, R. A. (1996) An evaluation of the accuracy of kernel density estimators for home range analysis. Ecology 77: 2075-2085.

Serra, G. (2002) Proposal for an action plan to protect wildlife of Palmyrean desertic steppe. Unpublished report to Syrian Ministry of Environment and FAO/DGCS (Italian Development Cooperation Programme), Project GCP/SYR/oog/ITA.

Serra, G. (2003) Discovery of Northern Bald Ibises in Syria. World Birdwatch 25: 10-13.

Serra, G. (2007) Ecotourism in the Palmyra desert, Syria. A feasibility study. Unpublished report to BirdLife International http://www.ecotourismsyria.com/pdf/feasibility \% 2oecotourism \% 2opalmyra \% 2oBLI $\%$ 20- \% 2olight $\%$ 2oversion.pdf, downloaded on 26 April 2010.

Serra, G. (2008) Ecotourism and nature tourism in Palmyra. In: Palmyra Region Strategic Action Plan: A Strategy for Sustainable Development. Unpublished report to Municipality Administration Modernization (MAM) project MED/2004/6264: EUROPE AID/119822/SV/SY.

Serra, G., Abdallah, M., Abdallah, A., Al Qaim, G., Fayed, T., Assaed, A. and Williamson, D. (2004) Discovery of a relict breeding colony of Northern Bald Ibis Geronticus eremita in Syria: still in time to save the eastern population? Oryx 38: $1-7$.

Serra, G., Murdoch, D., Turkelboom, F., Travert, F., Mujawer, Y. and Scott, D. (2006) Sabkhat al-Jabbul, a threatened Ramsar wetland in Syria. Sandgrouse 28: 127-141.

Serra, G., Abdallah, M. S. and Al Qaim, G. (2008) Feeding ecology and behaviour of the last known surviving oriental Northern Bald Ibises Geronticus eremita (Linnaeus 1758) at their breeding quarters in Syria. Zool. Middle East 43: 55-68.

Serra, G., Peske, L., Abdallah, M. S., Al Qaim, G. and Kanani, A. (2009a) Breeding ecology of the last oriental N. Bald Ibises in the Syria desert. J. Ornithol. 150: 769-782.

Serra, G., Nahaz, M. M., Idan, M., Peske, L., Savioli, A., Bruschini, C. and Alomari, K. (2009b) Assessment and characterization of the Ibis Protected Area in the Palmyra 
Desert - a proposed 5-year management and development framework. Damascus, Syria: IUCN/DGCS (Italian Development Cooperation Programme).

Serra, G., Mirreh, M., Kaddour, H., Razzouk, T., Al Jundi, A., Kanani, A., Batello, C. and Williamson, D. (2009c) Assessment and characterization of Al Talila Reserve and surrounding Palmyrean desert. Damascus, Syria: IUCN/DGCS (Italian Development Cooperation Programme).

Vashon, J. H., Meehan, A. L., Jakubas, W. J., Organ, J. F., Vashon, A. D., Mc Laughlin, C. R., Matula, G. J., Jr, and Crowley, S. M. (2008) Spatial ecology of a Canada Lynx population in Northern Maine. J. Wildlife Manage. 72: 1479-1487.

Ward, P. and Zahavi, A. (1973) The importance of certain assemblages of birds as "information-centres" for food-finding. Ibis 115: 517-534.

Worton, B. J. (1989) Kernel methods for estimating the utilization distribution in home-range studies. Ecology 70: 164-168.

Xiao-Ping, Y., Xiu-Yun, C., Xia, L., WenGui, C. and Liang, S. (2009) Return of the Crested Ibis Nipponia nippon: a reintroduction programme in Shaanxi province, China. Birding ASIA 11: 80-82.

\section{GIANLUCA SERRA*}

Via Nuova delle Molina 6, 50010 Fiesole, Florence, Italy.

\section{CLAUDIA BRUSCHINI}

Dipartimento di Biologia Evoluzionistica, Università degli Studi di Firenze, via Romana 17, 50125, Florence, Italy.

\section{JEREMY A. LINDSELL}

The Royal Society for the Protection of Birds, The Lodge, Sandy, Beds SG19 2DL, UK.

\section{LUBOMIR PESKE}

Conservation Biologist, Slezska 43, Prague 3, 13000, Czech Republic.

\section{AHMED KANANI}

Director of Ibis Protected Area, General Badia Commission, Palmyra, Syria.

*Corresponding author; e-mail: abunug@gianlucaserra.com

Received 28 April 2010; revision accepted I December 2010;

Published online 11 February 2011 